\title{
Phosphate Enrichment Regulates the Interplay \\ Between Deterministic and Stochastic Processes of Bacterioplankton Community Assembly in a Subtropical Bay Impacted by Thermal Discharge
}

\section{Ye Chen}

Jinan University

LingLin Wan

Jinan University

Guibin Ma

Jinan University

Xingyu Song

South China Sea Institute of Oceanology Chinese Academy of Sciences

Guo Jia

Jinan University

Lijuan Ren ( $\nabla$ lijuanren@jnu.edu.cn )

Jinan University https://orcid.org/0000-0002-9299-7527

\section{Bo-Ping Han}

Jinan University

\section{Qinglong Wu}

Nanjing Institute of Geography and Limnology Chinese Academy of Sciences

\section{Research Article}

Keywords: Phosphate enrichment, bacterioplankton community, phylogenetic assembly, environmental filter, subtropical bay

Posted Date: February 1st, 2022

DOI: https://doi.org/10.21203/rs.3.rs-1198212/v1

License: (c) (1) This work is licensed under a Creative Commons Attribution 4.0 International License.

Read Full License 
1 Phosphate enrichment regulates the interplay between deterministic and

2

3

4

5 Ye Chen ${ }^{1 \#}$, LingLin Wan ${ }^{1 \#}$, Guibin Ma ${ }^{1}$, Xingyu Song ${ }^{2}$, Guo Jia ${ }^{1}$, Lijuan Ren ${ }^{1,2^{*}}$,

$6 \quad$ Bo-Ping $\operatorname{Han}^{1}$, and Qinglong. $\mathrm{Wu}^{3}$

7

8

9

stochastic processes of bacterioplankton community assembly in a subtropical bay impacted by thermal discharge ${ }^{1}$ 7

${ }^{1}$ Department of Ecology and Institute of Hydrobiology, Jinan University, Guangzhou,

\section{China}

${ }^{2}$ Key Laboratory of Tropical Marine Bio-resources and Ecology \& Guangdong Provincial Key Laboratory of Applied Marine Biology, South China Sea Institute of Oceanology, Chinese Academy of Sciences, Guangzhou, China ${ }^{3}$ State Key Laboratory of Lake Science and Environment, Nanjing Institute of Geography and Limnology, Chinese Academy of Sciences, Nanjing, China

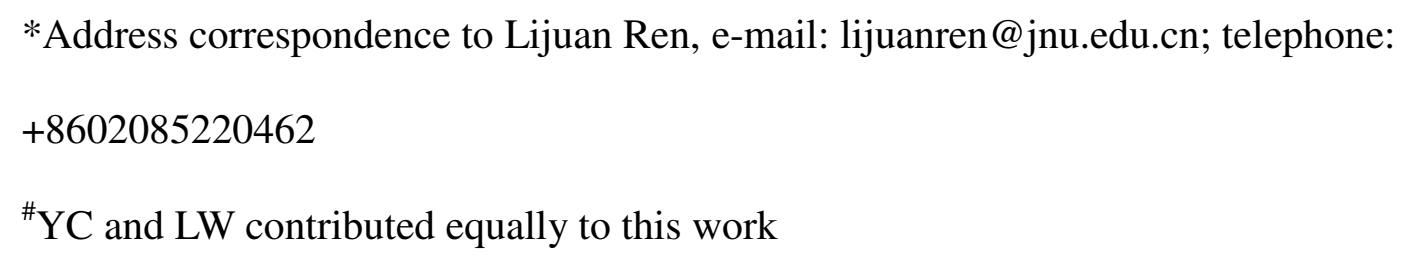

Running Head: Bacterioplankton response to environmental heterogeneity

\footnotetext{
${ }^{1}$ Author contributions' statement

LR and XS conceived the study, conducted the fieldwork, analyzed the data, wrote the manuscript, and provided funding. YC, LW, GM, and JG analyzed the data and wrote the manuscript. QLW and BPH contributed to the manuscript revision and editing.
} 


\section{Abstract}

Increasing anthropogenic activities has caused intensive environmental issues and undesirable ecological impacts on coastal bay ecosystems. Bacterioplankton play critical roles in ecological functioning of the bay ecosystems, but much remains to be learned regarding the response of bacterioplankton community assembly to heterogeneous environmental issues in the bay ecosystems and its underlying mechanisms. In this study, we used the phylogenetic framework to analyze the bacterioplankton community assembly in the subtropical Daya Bay, where the habitats are connected by water flows and tides and their trophic status are subject to intensive environmental stress induced by human activities (e.g., thermal discharge and nutrient release from aquaculture). We found bacterioplankton community compositions (BCCs) among the sampling habitats in the Daya Bay showed obvious spatial heterogeneity. The spatial distributions of BCCs were significantly shaped by phosphate concentration among the examined environmental factors. We observed that between pairwise sampling habitats, the BCC dissimilarity significantly increased with the differences in seawater phosphate concentration. Compared with stochastic processes, phosphate enrichment imposed stronger effects of environmental filtering in determining bacterioplankton community assembly in the subtropical bay, and bacterioplankton communities tended to be higher phylogenetically clustered in more phosphate-enriched habitats. In summary, we propose that phosphate is a major environmental determinant in the subtropical Daya Bay impacted by thermal discharge and regulates the interplay between deterministic and stochastic processes underlying bacterioplankton community assembly.

Keywords: Phosphate enrichment; bacterioplankton community; phylogenetic assembly; environmental filter; subtropical bay 


\section{Introduction}

In marine ecosystems, coastal bays are essentially important to human society for various services they provided, such as supporting, regulating, and provisioning services (Barbier et al. 2011; Temmink et al. 2020). However, due to the increasingly and intensively anthropogenic activities around the bay ecosystems, currently, many coastal bay ecosystems are facing heterogeneous environmental issues (Lefcheck et al. 2018; He and Silliman 2019). Existing studies indicate that eutrophication, environmental pollution, and harmful algal bloom have occurred frequently in many coastal bay ecosystems and caused a decrease in biodiversity, a collapse of living organisms, and an ecological imbalance (McLusky and Elliott 2004; Cloern and Jassby 2010; Stauffer et al. 2020). The influence of heterogeneous environmental issues on marine planktonic community has been a hot issue in the field of bay environmental protection (Matear et al. 2019). Bacterioplankton, an integral component of marine planktonic community, play important roles in ecosystem functioning of coastal bays (Falkowski et al. 2008; Wang et al. 2020). Due to the short generation time and frequent ecological drift of bacterioplankton, its community diversity may change synchronously with seawater environmental changes (Luo and Moran 2015) and have influence on the resistance and resilience of other organisms to heterogeneous environmental issues (Bissett et al. 2013). Despite the ecological functioning of bacterioplankton community, much remains to be learned regarding the response of bacterioplankton community assembly to heterogeneous environmental issues in the coastal bay ecosystems and its underlying mechanisms.

It is a longstanding challenge to understand the mechanisms underlying bacterioplankton community assembly in natural aquatic ecosystems (Quattrini et al. 2017; Shen et al. 2018; Aguilar and Sommaruga 2020). One promising approach to 
understand the mechanisms underlying bacterioplankton community assembly is the use of the phylogenetic framework (Webb 2000; Webb et al. 2002). The changes in the relative influences of deterministic and stochastic processes across heterogeneous environmental issues can be inferred in the phylogenetic framework, by comparing observed community phylogenetic structure with randomization procedures (Webb et al. 2002; Cavender-Bares et al. 2004; Quattrini et al. 2017). Based on the assumption that closely related phylogenetic taxa are more likely to have similar niches in phylogenetic framework, a nonrandom observed phylogenetic structure is expected to suggest the deterministic processes of community assembly (Webb 2000; Wiens et al. 2010). Deterministic processes assume that bacterioplankton community structure is controlled by deterministic factors such as environmental heterogeneity and species interactions. Meanwhile, stochastic processes suppose bacterioplankton community structure is shaped by stochastic processes, such as probabilistic dispersal and random birth/death events (Hubbell 2011). Because both deterministic and stochastic processes may play important roles in shaping bacterioplankton community assembly, it comes up a question of that how their relative contributions of stochastic and deterministic processes change with environmental heterogeneity in natural bay ecosystems.

Daya Bay is one of the most socially and economically important bay in the northeast part of the Pearl River estuary of China (Wang et al. 2008). As a core region of Pearl River Delta, the coastal area of this bay has been experiencing rapid economic development during the past decades. Since the operation of the first large-capacity commercial nuclear power plant, namely Daya Bay Nuclear Power Station in 1994, more and more agriculture, industries, and urbanization have been carried out around the Daya Bay (Tang et al. 2003; Wang et al. 2011). The 
increasingly anthropogenic activities around the bay ecosystems led to undesirable heterogeneous environmental issues and subsequent ecological impacts on the Daya bay ecosystems (Wu et al. 2017). It is showed that the Daya Bay are suffering long-term thermal pollution from the cooling systems of the two nuclear power stations, Daya Bay nuclear power station and Ling'ao nuclear power station (completed in 2002) (Tang et al. 2003; Wei et al. 2013). In addition, the bay is facing long-term eutrophication caused by the excess nutrient input from the domestic sewage and aquaculture (Song et al. 2004; Sun et al. 2006). Long-term thermal pollution and nutrient (e.g., nitrogen and phosphorus) excess might be a "stress" event that acts as an environmental filter selecting bacterioplankton taxa with suitable biological traits and filter out other members from the local species pool (Dai et al. 2017). Besides the deterministic processes of environmental factors, dispersal might simultaneously play important roles in shaping the patterns of the bacterioplankton community assembly in the Daya Bay ecosystem, since frequently exchanges of different bacterioplankton seed banks across different patches through water flows and tides in the bay (Ren et al. 2019). The frequent dispersal of bacterioplankton across different patches might result in the presence of bacterioplankton taxa in places that are less suitable for them and weakening the deterministic effects of environmental factors (Juračka et al. 2016; Wisnoski and Lennon 2021).

In this study, we used a phylogenetic framework to study bacterioplankton community assembly and the underlying determining mechanisms based on $16 \mathrm{~S}$ rRNA high-throughput sequencing collected from a set of habitats located in the Daya Bay sampled in a wet summer season. We hypothesized that (1) although bacterioplankton seed banks can frequently exchange across different habitats through water flows and tides in a typical subtropical semi-enclosed bay, the patterns of the 
bacterioplankton community assembly might be dominantly shaped by deterministic processes of environmental heterogeneity; (2) long-term thermal pollution and nutrient input might act as key environmental filters in determining bacterioplankton community assembly, causing phylogenetically clustered of bacterioplankton communities in the subtropical Daya Bay. Our study might contribute to a broader understanding of the ecological effects of environmental disturbance to subtropical bay and benefit the management of the subtropical bay.

\section{Materials and methods}

\section{Study area}

Daya Bay is located in the northern South China Sea $\left(114.3^{\circ} \mathrm{E}\right.$ to $114.5^{\circ} \mathrm{E}$, $22.3^{\circ} \mathrm{N}$ to $22.5^{\circ} \mathrm{N}$ ) between Shenzhen and Huizhou in Guangdong province near Hong Kong (Fig. 1). It is one of the largest and most important semi-closed bays along the southern coast of China with an area around $600 \mathrm{~km}^{2}$, a depth between 6 and $15 \mathrm{~m}$, and an average annual water temperature from $22.5-23.5^{\circ} \mathrm{C}$. Around the Daya Bay, there are two nuclear power stations (the Daya Bay nuclear power station and Lingao nuclear power station) (Wang et al. 2008). Heated water is released into water body at a unified outlet site away from the intake points of the cooling system of the two nuclear power stations, and the seawater temperature of the area strong affected by thermal pollution is heated over the whole year. Meanwhile, the bay is suffering eutrophication caused by the excess nutrient input from the domestic sewage and aquaculture (Sun et al. 2006).

We set 12 sampling sites in the Daya Bay (S1-S12, Fig. 1), and sampled the seawater in August 2017, including the marine aquaculture area seriously affected by human activities (Fanhe harbour aquaculture area S1; Xiaoguiwan aquaculture area 
S5; Dapengao aquaculture area S10), nuclear power station thermal pollution area (S9), petrochemical pollution area (S6), the estuary area (S11 and S12), river inflow area (S2), and site $\mathrm{S} 7$ that was less affected by human activities.

\section{Sample collection and environment factor analysis}

At each sampling site, we set three replicates. $5 \mathrm{~L}$ surface seawater was collected at each replicate site and was filtered through 0.2-m-pore-size Isopore filters (Millipore, Billerica, MA, USA). The filters with microbial biomass were stored at $70^{\circ} \mathrm{C}$ for further analysis. Water temperature (T), dissolved oxygen (DO), salinity and $\mathrm{pH}$ were measured in situ at each replicate site by using multi-parameter water quality analyzer (YSI 6600, Yellow Springs, OH, USA). $500 \mathrm{~mL}$ surface seawater was further collected at each replicate site for the measurement of nutrient conditions. According to a standard procedure (GB 17378.4-2007), seawater ammonium nitrogen $\left(\mathrm{NH}_{4}{ }^{+}-\mathrm{N}\right)$, nitrate nitrogen $\left(\mathrm{NO}_{3}{ }^{-}-\mathrm{N}\right)$, phosphate $\left(\mathrm{PO}_{4}{ }^{3-}-\mathrm{P}\right)$, and silicate $\left(\mathrm{SiO}_{3}{ }^{2-}-\mathrm{Si}\right)$ concentrations were determined using a UV-visible spectrophotometer (UV2450, Shimadzu, Tokyo, Japan).

\section{DNA extraction, PCR amplification, high-throughput sequencing and data}

\section{processing}

\section{Microbial genomic DNA was extracted using PowerWater DNA Isolation Kit} (MoBio Laboratories, Carlsbad, CA) and was purified by PowerClean DNA Clean up Kit (Mo Bio Laboratories, Carlsbad, CA, USA). With 60 ng DNA as template, PCR amplification was performed in the bacterial $16 \mathrm{~S}$ rRNA V3 and V4 regions using the primer with $10 \mathrm{mM}$ barcode and $25 \mu \mathrm{L} 2 \times$ PCR Premix Taq. The amplification primers were F341 (5 '-CCTACGGGAGGCAGCAG-3') and R806 (3

\footnotetext{
'-GGACTACGGGTTCTAAT-5'). PCR reactions included an initial denaturation at
} 
$94{ }^{\circ} \mathrm{C}$ for $5 \mathrm{~min}$, followed by 30 cycles of $30 \mathrm{~s}$ at $94^{\circ} \mathrm{C}, 30 \mathrm{~s}$ at $52{ }^{\circ} \mathrm{C}$, and $30 \mathrm{~s}$ at $72{ }^{\circ} \mathrm{C}$ and the final extension for 10 minutes $\left(72^{\circ} \mathrm{C}\right)$. When the PCR amplification was completed, the fragment length and concentration of PCR products were detected by $1 \%$ agarose gel electrophoresis and the positive amplicons were quantified using the PicoGreen dsDNA assay kit (Invitrogen Corporation, Carlsbad, CA, USA).

Subsequently, the PCR products were equally combined and purified with Zymo's Genomic DNA Clean \& Concentrator kit (Zymo Research Corporation, Irvine, CA, USA). Finally, amplicons were sequenced using PE250 on Illumina Hiseq2500 platform.

Raw sequences were processed with the mothur software package (version 1.30.0, 2013) (http://www.mothur.org) according to the MiSeq standard operating procedure (Kozich et al. 2013). Briefly, the raw sequences were combined, denoised, trimmed, quality-filtered, and aligned to the SILVA v132 databases using mother (Kozich et al. 2013). The high-quality sequences were then classified using the SILVA v132 databases at the recommended bootstrap threshold of $80 \%$ (Wang et al. 2007). The lineages belonging to chloroplasts, mitochondria, archaea or eukaryotes were removed and the high-quality sequences were then clustered into operational taxonomic units (OTUs) at a 97\% similarity level. All singletons of OTUs and OTUs occurring in less than two samples were removed in the further analyses for minimizing bias caused by sequencing depth. Moreover, of the whole sample set, the minimum number of sequences was randomly subsampled to correct for differences in sequencing depth.

\section{Diversity analysis}

Taxonomic richness and Shannon-Wiener index of bacterioplankton community were calculated using the "vegan" packages in R. The dissimilarities of 
bacterioplanton community compositions (BCCs) between sites were performed based on both of the Bray-Curtis and the UniFrac distance by using the "vegan" packages in $\mathrm{R}$.

\section{Phylogenetic framework}

The phylogenetic framework was performed, and both of the mean-nearest-taxon-distance (MNTD) and the standardized-effect size of the MNTD (SES.MNTD) were calculated by using package "picante" in R. The null model was performed by shuffling taxon labels 999 times across the tips of the phylogenetic tree using a given tree topology and branch lengths to randomize phylogenetic relationships among OTUs. By comparing the difference between the observed community and the random community, the main ecological processes of bacterioplankton community assembly was determined in the Daya Bay. SES.MNTD means the differences in MNTD between the observed communities and the mean value of the 999 null communities divided by the standard deviation of the MNTD in the 999 null communities (Webb 2000). When SES.MNTD values greater than 2, it indicates phylogenetic overdispersion (taxa are more distantly related than would be expected random). If SES.MNTD values less than 2, it suggests phylogenetic clustering (taxa are more closely related than would be expected at random). When SES.MNTD values between -2 and 2 , it represents that stochastic processes dominate in the bacterioplankton community assembly (Webb 2000; Webb et al. 2002).

\section{Statistical analyses}

We performed the analysis of multiple regression tree (MRT) in which the BCCs were the response variable and the environmental variables were the explanatory variable by using the "mvpart" packages in R (version 4.0). The relative abundances 
of OTUs of the main lineages or clades of bacterioplankton communities along the phosphate gradient were depicted in a heat map using the pheatmap command in the “pheatmap” package in R. A partial Mantel test with 9,999 permutations was performed to calculate partial matrix correlations between three dissimilar matrices: the BCC matrix, each selected environment variable, and the conditional matrix of the remaining environment variables (Legendre and Legendre 2012). Mantel test was used to test the relationship between environment difference and bacterial sub-community dissimilarity. The correlations among environmental factors (Pearson correlation coefficients) were examined by Pearson regression. The distributions of both taxonomy-based and phylogeny-based BCCs in the Daya Bay were visualized by using nonmetric multidimensional scaling (NMDS) in the vegan package in R.

\section{Accession numbers}

The sequence data were submitted to the National Center for Biotechnology Information (NCBI) Sequence Read Archive (SRA) (https://www.ncbi.nlm.nih.gov/sra) under accession number PRJNA765469.

\section{Results}

Of the quality sequences, $97.7 \%$ were classified at the phylum level and 20 phyla were obtained. The dominant phyla across all sampled habitats were Alphaproteobacteria, Cyanobacteria, Bacteroidetes, and Actinobacteria, representing approximately $51.0 \%, 22.8 \%, 9.8 \%$ and $9.7 \%$ of the total sequences, respectively (Fig. S1, Fig.2). In addition, Gammaproteobacteria (3.3\%), Planctomycetes (2.5\%), Deltaproteobacteria $(0.16 \%)$, Firmicutes $(0.13 \%)$, and Acidobacteria $(0.04 \%)$ were present in most sampled habitats but with low relative abundance (Fig. S1). We observed that bacterioplankton (sub)phylum compositions at S1 and S3 stations was 
similar, and the BCCs was mainly composed of Alphaproteobacteria (Fig. S1, Fig.

2e). The relative abundance of Bacteroides was much higher in S1, S3, S11, S12 than the other sites, suggesting that Bacteroides was more suitable to the habitats of the top and the estuary of the Daya Bay ecosystem (Fig. S1, Fig. 2b). However, Cyanobacteria had the highest relative abundance at S7, S8, S9, and S10, where was strongly affected by the thermal pollution from the nuclear power plants (Fig. S1, Fig. 2c). In contrast with other phyla, Actinobacteria were mainly found in estuary of the bay (Fig. S1, Fig. 2a).

The average water temperature in the subtropical Daya Bay was $29.78 \pm 1.14^{\circ} \mathrm{C}$ with the highest at site $\mathrm{S} 9\left(32.03^{\circ} \mathrm{C}\right)$, which was strongly affected by thermal pollution of the cooling system of the nuclear power stations (Fig. S2). The average salinity of the Daya Bay was $28.84 \pm 3.03 \%$, with the highest at site S11 (33.33\%o) and the lowest at $\mathrm{S} 1\left(22.78 \%\right.$ ) (Fig. S2). The concentration of $\mathrm{PO}_{4}{ }^{3-}-\mathrm{P}, \mathrm{NO}_{3}{ }^{-}-\mathrm{N}$, $\mathrm{NH}_{4}{ }^{+}-\mathrm{N}$ and $\mathrm{SiO}_{3}{ }^{2-}$ showed a decreased tendency from the top (site $\mathrm{S} 1$ and $\mathrm{S} 3$ ) to the estuary (site S11 and S12) of the Daya Bay (Fig. S2). Among the measured environmental factors, we found that seawater phosphate was the best predictor of BCCs in the Daya Bay (Fig. S3). The mantel test also showed that phosphate was significantly correlated with differences in BCCs across different bacterial phyla and subphyla in the water bodies (Fig. 3a). Therefore, we further explored the relationship between the concentration $\mathrm{PO}_{4}{ }^{3-}-\mathrm{P}$ and the relative abundance of the dominant phyla. The relative abundances of Actinobacteria (Fig. 3b), Cyanobacteria (Fig. 3d), Planctomycetes (Fig. 3e), and Gammaprotecteria (Fig. 3g) decreased linearly with phosphate concentration, while the relative abundances of Bacteroidetes (Fig. 3c) and Alphaproteobacteria (Fig. 3f) were positively correlated with phosphate concentration. At the site with high phosphate concentration, the main lineage or clades were mostly 
composed of the bacteria Saprospiraceae and Croinitomicaceae of Bacteriodetes, and Rhodobacteraceae, Novosphingobium and Tabrizicola of Alphaproteobacteria (Fig. 4), while NS4 marine group of Bacteriodetes, Synechococcus and Cyanobium of Cyanobacteria, and UBA10353 marine group of Gammaproteobacteria dominated in low phosphate concentration (Fig. 4).

The seawater phosphate was a key environmental factor in determining bacterioplankton community structure revealed by redundancy analysis (RDA) followed by temperature and silicate (Fig.S4). Bacterioplankton spatial distributions did not showed obvious geographical patterns (Fig. 5a and 5b), temperature (Fig. S5a and S5b) or silicate (Fig. S5c and S5d) patterns, but was arranged according to the phosphate concentrations as the low concentration (LPC), the medium concentration (MPC), and the high concentration (HPC) (Fig. 5c and 5d). The NMDS plot revealed that the BCCs of different spatial habitats but with the same phosphate concentration tend to be similar, suggesting the existence of strong linkages between phosphate concentration and community structure (Fig. 5c and 5d). Between pairwise sampling habitats, the BCC dissimilarity both based on Bray-Curtis and UniFrac distances significantly increased with the differences in seawater phosphate concentration (Fig. 5e and 5f). Moreover, we found seawater phosphate concentration also had significantly positive correlations with bacterioplankton alpha diversity, such as with OTU richness $\left(\mathrm{R}^{2}=0.15, p<0.05\right)$ and Shannon-Wiener index $\left(\mathrm{R}^{2}=0.12, p<0.05\right)$ (Fig. S6a and S6b).

To understand the mechanisms underlying bacterioplankton community assembly across heterogeneous environmental issues, the phylogenetic framework was performed, and we found a significant negative correlation between the MNTD and the concentration of phosphate (Fig. 6a). The site with the highest phosphate 
concentration had the lowest MNTD, indicating that the higher the phosphate concentration, the closer the phylogenetic relationships between the nearest bacterial taxa. Moreover, we observed that, the standardized-effect size of the MNTD (SES.MNTD) was significantly lower than zero and decreased linearly with increasing the phosphate concentration $\left(\mathrm{R}^{2}=0.21 ; p<0.01\right.$, Fig. $\left.6 \mathrm{~b}\right)$.

\section{Discussion}

In this study, we examined bacterioplankton community assembly and the underlying mechanisms in the typical subtropical semi-enclosed Daya Bay ecosystem. We found that the spatial pattern of BCCs was dominantly shaped by deterministic processes. Among the environmental factors, phosphate concentration was the key environmental determinant of the assembly patterns of marine bacterioplankton communities. Apparent phosphate concentration-related patterns of bacterioplankton community compositions, diversity, and phylogenetic structure were observed in the Daya Bay impacted by thermal discharge.

\section{The bacterioplankton metacommunity assembly was predominantly shaped by}

\section{deterministic processes}

In metacommunity theory, dispersal plays an important role in determining the assembly of bacterioplankton communities between habitats of aquatic environments (Leibold et al. 2004). High dispersal rates may result in bacterioplankton taxa surviving in habitats that less suitable for their growth, and in contrast, low dispersal rates of bacterioplankton taxa may lead to dispersal limitation and thus lead to significant spatial variations (Juračka et al. 2016; Wisnoski and Lennon 2021). In this study, we found that bacterioplankton dispersal among the sampling habitats by water flows and tides in the Daya Bay did not result in BCC spatial homogeneity. In contrast, 
significant heterogeneity in BCCs was found across different sampling sites in the

Daya Bay. Among the environmental factors, phosphate concentration was found to be the key environmental determinant of the assembly patterns of marine bacterioplankton communities and apparent phosphate concentration-related patterns of BCC distributions were observed in the Daya Bay. As inferred in previous studies, this finding also suggests that bacterioplankton community assembly in interconnected aquatic habitats was predominantly shaped by deterministic processes of environmental factors, rather than by dispersal (Shen et al. 2018; Ren et al. 2019; Aguilar and Sommaruga 2020). A number of studies have demonstrated that BCCs can rapidly track changes in the environment (Van Der Gucht et al. 2001; Muylaert et al. 2002). Thus, the persistence of newly arrived populations of bacterioplankton migrating through flowing water was more likely to be determined by deterministic processes of heterogeneous habitats, rather than by dispersal (Logue and Lindström 2010).

\section{Phosphate enrichment increased bacterioplankton alpha diversity}

The nutrient condition in the Daya Bay has changed from previous N-limited to current P-limited for the "excess nitrogen" input (He et al. 2005; Zhang et al. 2020). Previous studies have revealed the potential phosphorus limitation of phytoplankton growth in Daya Bay (Wang et al. 2008; Wu et al. 2017; Zhang et al. 2018).

Phosphorus limitation exists not only for phytoplankton, but also for bacterioplankton. Compared to phytoplankton, bacterioplankton can assimilate phosphorus more effectively because of their larger specific surface area, and they have a lower half-saturation constant for phosphate than phytoplankton (Currie and Kalff 1984). In addition, the N:P ratio of phytoplankton biomass was generally about $16: 1$, which is much higher than that of heterotrophic bacteria (Kirchman 2000), resulting in a higher 
efficiency of phosphorus requirement for bacterioplankton than phytoplankton. It is suggested that bacterial cells were difficult to divide when phosphate concentrations were limit (Zweifel et al. 1993; Yuan et al. 2011). The addition of phosphate in seawater might therefore enhance bacterial cell division and support for higher abundance and diversity of bacterioplankton community (Yuan et al. 2011).

In our study, we found bacterioplankton alpha diversity (the OTU richness and Shannon-Wiener index) were significant increased with phosphate enrichment, and the S1 site with the highest phosphate concentration also had the highest bacterioplankton OTU richness and Shannon-Wiener index. The S1 site in our study was located near the Fanhe harbor aquaculture area. Due to the rapid development of marine aquaculture industry, aquaculture was carried out since the 1990s on mangrove beaches and nutrients were fed into the water body in the form of bait (Wu et al. 2014). It was reported that only about $33 \%$ of phosphate was assimilated by fish during cage fish-farming, with the rest being retained in various forms in the cultured environment (Bouwman et al. 2013). It is suggested that sufficient nutrient supply is generally associated with enhanced primary productivity (Whitney et al. 2005). This enhanced primary productivity may lead to increased bacterioplankton alpha diversity for the reduced resource competitive exclusion as "the larger pie can be divided into more pieces" (Brown 1981; Fuhrman et al. 2008).

\section{Heterogeneity of BCCs across phosphate gradients}

We found that the sites with higher phosphate concentration were dominated by Alphaproteobacteria. Alphaproteobacteria are an "opportunistic group" that respond quickly to nutritional pulses, and they are found that dominate in plenty eutrophic water (Pinhassi and Berman 2003). At the lineage or clade level of the top 30 OTUs, we also observed a larger BCC variations at higher phosphate-concentration sites by 
compared to the other sites. For higher phosphate-concentration sites, the relative abundance of Rhodobacteraceae, Novosphingobium and Saprospiraceae was obvious increased. We found the OTU with the highest relative abundance belonged to the Rhodobacteraceae family. Rhodobacteraceae (Alphaproteobacteria) were among the nine most widely distributed bacterial lineages in marine habitats (Garrity et al. 2005). Many bacterial taxa of Rhodobacteraceae are aerobic heterotrophs and have been identified as key players in organic carbon and sulfur cycling (González et al. 1999; Moran et al. 2003; Newton et al. 2010). It has been reported that Rhodobacteraceae often existed in an environment rich in nitrogen/phosphorus nutrients, and it can use the soluble organic matter released by phytoplankton to sustain its own growth (Jones et al. 2007; Beck et al. 2014). Furthermore, recent studies suggest that the Rhodobacteraceae showed the highest response to the phosphorus amendment in northwest coastal Mediterranean waters (Sánchez et al. 2017). Novosphingobium was another abundant taxon in phosphorus-enriched habitats. Previous study revealed that the main polar lipids of Novosphingobium were bisphosphatidylglycerol, phosphatidylethanolamine, phosphatidylcholine (Chen et al. 2015). Bacterial taxa belonging to Novosphingobium can therefore use surrounding phosphorus efficiently. The enrichment of seawater phosphorus conditions may enhance bacterial growth and increase its environmental relative abundance of Novosphingobium. Many studies about Saprospiraceae indicated that they were associated with the degradation of organic matter (Schauer et al. 2005; Chen et al. 2014). Shifts in the relative abundance of these bacterial taxa under phosphorus enrichment may alter the bacterioplankton community structure (Lebaron et al. 2001). Moreover, the enrichment of phosphate can stimulate the growth of protozoa (Caron and Countway 2009), which might cause an increase in predation pressure on bacterioplankton taxa, and resulted in an 
accelerated variations in the BCCs in phosphate-enriched habitats (Chen et al. 2016).

392

\section{Bacterioplankton communities turned to be more phylogenetic clustering in}

\section{higher phosphate-concentration seawater}

It is important to elucidate the ecological mechanisms underlying microbial community assembly in community ecology (Webb et al. 2002; Zhou and Ning 2017). In this work, we observed that phylogenetic clustering of the most closely related OTUs increased linearly with phosphate enrichment. This observation raised the following question: why the bacterioplankton community turned to be more phylogenetically clustered at sites with higher phosphate concentrations? In our analyses of the diversity and composition of bacterioplankton, we observed that phosphate was a key environmental factor, which increased the heterogeneity of community compositions and alpha diversity. Therefore, we proposed that the direct or indirect environmental filtering effect may be increased at the sites where the phosphate concentration was high. This result was consistent with the observations of the bacterial communities in some lakes and rivers (Horner-Devine and Bohannan 2006; Mykrä et al. 2016). The phylogenetic clustering has been interpreted as evidence of environmental filtering, where a group of closely related species share a trait, or suite of traits, that allow them to persist in a given habitat (Webb et al. 2002). Our results suggest that environmental filtering may be more important than stochastic processes for the assembly of bacterial communities. Recent studies have shown that long-term coastal nutrient increase significantly alters the composition (Fodelianakis et al. 2014), assembly process (Xiong et al. 2015) and function (Zhang et al. 2015) of the bacterioplankton community. Usually, the differences between bacterial communities are closely related to the nutritional level (Dai et al. 2017; Ren et al. 2017). It is showed that with the increase of nutritional level (long-term and 
continuous interference), the determinism of bacterial community assembly exhibited an elevated trend (Dai et al. 2017). They thought that long-term nutrient (phosphate) excess is a "stress" event that acted as an environmental filter, which could select species with suitable biological traits and exclude (filter out) other members from the local species pool. Similarly, in our study, the assembly of bacterioplankton community was dominantly shaped by deterministic processes in the subtropical Daya Bay. Thus, the most closely related OTUs (SES.MNTD) were more phylogenetically clustered in higher phosphate concentration sites.

\section{Conclusion}

Our results showed that the bacterioplankton community assembly was predominantly shaped by deterministic processes, and phosphate was a major environmental determinant in the subtropical Daya Bay. We observed that phosphate enrichment not only significantly increased the diversity of bacterioplankton communities, but also largely shifted the community compositions. Compared stochastic processes, phosphate enrichment imposed stronger effects of environmental filtering in determining marine bacterioplankton community assembly in the subtropical Daya Bay, and bacterioplankton communities tended to be higher phylogenetically clustered in more phosphate-enriched habitats. We therefore proposed that among the heterogeneous environmental issues in Daya Bay, phosphate enrichment was a major environmental determinant, regulating the interplay between deterministic and stochastic processes and shaping the patterns of marine bacterioplankton biodiversity. Our research might contribute to a broader understanding of the ecological effects of environmental disturbance to subtropical bay and benefit the management of the subtropical bay, during which, the phosphate emissions should be strictly controlled for their strong deterministic effects in shaping 

marine biological communities.

442 Acknowledgements We acknowledge Meiting Tan, Fuwu Xie, Yadong Huang,

443 Jiaxing Liu, Chenhui Xiang, Weiwei Liu, and Kaizhi Li for assistance with

444 experimental sampling, data analyses and manuscript revision.

445 Funding This work was supported by National Science Foundation (31870445,

$44641890853,32171517)$ and State Key Laboratory of Lake Science and Environment

447 (2018SKL007).

448 Author contributions' statement LR and XS conceived the study, conducted the

449 fieldwork, analyzed the data, wrote the manuscript, and provided funding. YC, LW,

450 GM, and JG analyzed the data and wrote the manuscript. QLW and BPH contributed

451 to the manuscript revision and editing.

452 Conflicts of interest The authors declare no conflict of interest. 


\section{References}

454

455

456

457

458

459

460

461

462

463

464

465

466

467

468

469

470

471

472

473

474

475

476

477

478

479

480

481

482

483

484

485

486

487

488

489

490

491

492

493

494

495

496

497

498

499

500

501

Aguilar P, Sommaruga R (2020) The balance between deterministic and stochastic processes in structuring lake bacterioplankton community over time. Mol Ecol 29:3117-3130 doi: 10.1111/mec.15538

Barbier EB, Hacker SD, Kennedy C, Koch EW, Stier AC, Silliman BR (2011) The value of estuarine and coastal ecosystem services. Ecol Monogr 81:169-193 doi: $10.1890 / 10-1510.1$

Beck DA, McTaggart TL, Setboonsarng U, Vorobev A, Kalyuzhnaya MG, Ivanova N, Goodwin L, Woyke T, Lidstrom ME, Chistoserdova L (2014) The expanded diversity of Methylophilaceae from Lake Washington through cultivation and genomic sequencing of novel ecotypes. PLoS One 9:e102458 doi: 10.1371/journal.pone. 0102458

Bissett A, Brown MV, Siciliano SD, Thrall PH (2013) Microbial community responses to anthropogenically induced environmental change: towards a systems approach. Ecol Lett 16:128-139 doi: 10.1111/ele.12109

Bouwman L, Goldewijk KK, Van Der Hoek KW, Beusen AH, Van Vuuren DP, Willems J, Rufino MC, Stehfest E (2013) Exploring global changes in nitrogen and phosphorus cycles in agriculture induced by livestock production over the 1900-2050 period. Proc Natl Acad Sci 110:20882-20887 doi: $10.1073 /$ pnas. 1012878108

Brown JH (1981) Two decades of homage to Santa Rosalia: toward a general theory of diversity. Am Zool 21:877-888 doi: 10.1093/icb/21.4.877

Caron DA, Countway PD (2009) Hypotheses on the role of the protistan rare biosphere in a changing world. Aquat Microb Ecol 57:227-238 doi: 10.3354/ame01352

Cavender-Bares J, Ackerly DD, Baum D, Bazzaz F (2004) Phylogenetic overdispersion in Floridian oak communities. Am Nat 163:823-843 doi: 10.1890/0012-9658(2006)87[109:PSOFPC]2.0.CO;2

Chen N, Yu XJ, Yang JS, Wang ET, Li BZ, Yuan HL (2015) Novosphingobium tardum sp. nov., isolated from sediment of a freshwater lake. Antonie Van Leeuwenhoek 108:51-57 doi: 10.1007/s10482-015-0463-X

Chen XX, Wang K, Guo AN, Dong ZY, Zhao QF, Qian J, Zhang DM (2016) Excess phosphate loading shifts bacterioplankton community composition in oligotrophic coastal water microcosms over time. J Exp Mar Biol Ecol 483:139146 doi: $10.1016 /$ j.jembe.2016.07.009

Chen ZR, Lei XQ, Lai QL, Li Y, Zhang BZ, Zhang JY, Zhang HJ, Yang LX, Zheng W, Tian Y, Yu ZM, Xu H, Zheng TL (2014) Phaeodactylibacter xiamenensis gen. nov., sp. nov., a member of the family Saprospiraceae isolated from the marine alga Phaeodactylum tricornutum. Int J Syst Evol Microbiol 64:3496-3502 doi: 10.1099/ijs.0.063909-0

Cloern JE, Jassby AD (2010) Patterns and scales of phytoplankton variability in estuarine-coastal ecosystems. Estuaries Coasts 33:230-241 doi: $10.1007 / \mathrm{s} 12237-009-9195-3$

Currie DJ, Kalff J (1984) The relative importance of bacterioplankton and phytoplankton in phosphorus uptake in freshwater 1. Limnol Oceanogr 29:311321 doi: 10.4319/lo.1984.29.2.0311

Dai WF, Zhang JJ, Tu QC, Deng Y, Qiu QF, Xiong JB (2017) Bacterioplankton assembly and interspecies interaction indicating increasing coastal eutrophication. Chemosphere 177:317-325 doi: 10.1016/j.chemosphere.2017.03.034 
Falkowski PG, Fenchel T, Delong EF (2008) The microbial engines that drive earth's biogeochemical cycles. Science 320:1034-1039 doi: 10.1126/science.1153213

Fodelianakis S, Papageorgiou N, Pitta P, Kasapidis P, Karakassis I, Ladoukakis ED (2014) The pattern of change in the abundances of specific bacterioplankton groups is consistent across different nutrient-enriched habitats in Crete. Appl Environ Microbiol 80:3784-3792 doi: 10.1128/AEM.00088-14

Fuhrman JA, Steele JA, Hewson I, Schwalbach, MS, Brown MV, Green JL, Brown JH (2008) A latitudinal diversity gradient in planktonic marine bacteria. Proc Natl Acad Sci 105:7774-7778 doi: 10.1073/pnas.0803070105

Garrity G, Belland JA, Lilburn T (2005) Family I. Rhodobacteraceae fam. nov. In: Brenner, Krieg, Staley, Garrity (Eds.), Bergey's Manual of Systematic Bacteriology, vol. 2, Part C: The Alpha-, Beta-, Delta-, and Epsilonproteobacteria, second ed., vol. 2. Springer, New York, 161-268

González JM, Kiene RP, Moran MA (1999) Transformation of sulfur compounds by an abundant lineage of marine bacteria in the $\alpha$-subclass of the class Proteobacteria. Appl Environ Microbiol 65:3810-3819 doi: 10.1128/AEM.65.9.3810-3819.1999

He Q, Silliman BR (2019) Climate change, human impacts, and coastal ecosystems in the Anthropocene. Curr Biol 29:R1021-R1035 doi: 10.1016/j.cub.2019.08.042

He YX, Huang XP, Huang LM, Xu ZZ, Yue WZ, Zhang JL (2005) Annual variation and analysis of nutrients in aquaculture area of Daya Bay. Mar Environ Sci 24:20-23 doi: 10.1007/11428831_101

Horner-Devine MC, Bohannan BJ (2006) Phylogenetic clustering and overdispersion in bacterial communities. Ecology 87: S100-S108 doi: 10.1890/0012-9658(2006)87[100:PCAOIB]2.0.CO;2

Hubbell SP (2011) The unified neutral theory of biodiversity and biogeography (MPB-32). Princeton University Press, Princeton

Jones PR, Cottrell MT, Kirchman DL, Dexter SC (2007) Bacterial community structure of biofilms on artificial surfaces in an estuary. Microb Ecol 53:153-162 doi: 10.1007/s00248-006-9154-5

Juračka PJ, Declerck SA, Vondrák D, Beran L, Černý M, Petrusek A (2016) A naturally heterogeneous landscape can effectively slow down the dispersal of aquatic microcrustaceans. Oecologia 180:785-796 doi: $10.1007 / \mathrm{s} 00442-015-3501-5$

Kirchman DL (2000) Uptake and regeneration of inorganic nutrients by marine heterotrophic bacteria. In: Kirchman DL (Ed.) Microbial Ecology of the Oceans. Wiley-Liss, USA, pp 261-288

Kozich JJ, Westcott SL, Baxter NT, Highlander SK, Schloss PD (2013) Development of a dual-index sequencing strategy and curation pipeline for analyzing amplicon sequence data on the MiSeq Illumina sequencing platform. Appl Environ Microbiol 79:5112-5120 doi: 10.1128/AEM.01043-13

Lebaron P, Servais P, Troussellier M, Courties C, Muyzer G, Bernard, L, Schäfer H, Pukall R, Stackebrandt E, Guindulain T, Vives-Rego J (2001) Microbial community dynamics in Mediterranean nutrient-enriched seawater mesocosms: changes in abundances, activity and composition. FEMS Microbiol Ecol 34:255266 doi: 10.1111/j.1574-6941.2001.tb00776.x

Lefcheck JS, Orth RJ, Dennison WC, Wilcox DJ, Murphy RR, Keisman J, Gurbisz C, Hannam M, Landry JB, Moore KA, Patrick CJ, Testa J, Weller DE, Batiuk RA (2018) Long-term nutrient reductions lead to the unprecedented recovery of a temperate coastal region. Proc Natl Acad Sci 115:3658-3662 doi: 
10.1073/pnas. 1715798115

Legendre P, Legendre L (2012) Numerical ecology, 3rd edn. Elsevier, Amsterdam Leibold MA, Holyoak M, Mouquet N, Amarasekare P, Chase JM, Hoopes MF, Holt RD, Shurin JB, Law R, Tilman D, Loreau M, Gonzalez A (2004) The metacommunity concept: a framework for multi-scale community ecology. Ecol Lett 7:601-613 doi: 10.1111/j.1461-0248.2004.00608.x

Logue JB, Lindström ES (2010) Species sorting affects bacterioplankton community composition as determined by $16 \mathrm{~S}$ rDNA and $16 \mathrm{~S}$ rRNA fingerprints. ISME J 4:729-738 doi: 10.1038/ismej.2009.156

Luo HW, Moran MA (2015) How do divergent ecological strategies emerge among marine bacterioplankton lineages? Trends Microbiol 23:577-584 doi: 10.1016/j.tim.2015.05.004

Matear L, Robbins JR, Hale M, Potts J (2019) Cetacean biodiversity in the Bay of Biscay: suggestions for environmental protection derived from citizen science data. Mar Policy 109:103672 doi: 10.1016/j.marpol.2019.103672

McLusky DS, Elliott M (2004) The estuarine ecosystem: ecology, threats and management. Oxford University Press, Oxford

Moran MA, González JM, Kiene RP (2003) Linking a bacterial taxon to sulfur cycling in the sea: studies of the marine Roseobacter group. Geomicrobiol J 20:375-388 doi: 10.1080/01490450303901

Muylaert K, Van der Gucht K, Vloemans N, Meester LD, Gillis M, Vyverman W (2002) Relationship between bacterial community composition and bottom-up versus top-down variables in four eutrophic shallow lakes. Appl Environ Microbiol 68:4740-4750 doi: 10.1128/aem.68.10.4740-4750.2002

Mykrä H, Tolkkinen M, Markkola AM, Pirttilä AM, Muotka T (2016) Phylogenetic clustering of fungal communities in human-disturbed streams. Ecosphere 7:e01316 doi: 10.1002/ecs2.1316

Newton RJ, Griffin LE, Bowles KM, Meile C, Gifford S, Givens CE, Howard EC, King E, Oakley CA, Reisch CR, Reisch CR, Rinta-Kanto JM, Sharma S, Sun SL, Varaljay V, Vila-Costa M, Westrich JR, Moran MA (2010) Genome characteristics of a generalist marine bacterial lineage. ISME J 4:784-798 doi: 10.1038/ismej.2009.150

Pinhassi J, Berman T (2003) Differential growth response of colony-forming $\alpha$-and $\gamma$-proteobacteria in dilution culture and nutrient addition experiments from Lake Kinneret (Israel), the eastern Mediterranean Sea, and the Gulf of Eilat. Appl Environ Microbiol 69:199-211 doi: 10.1128/AEM.69.1.199-211.2003

Quattrini AM, Gómez CE, Cordes EE (2017) Environmental filtering and neutral processes shape octocoral community assembly in the deep sea. Oecologia 183:221-236 doi: 10.1007/s00442-016-3765-4

Ren LJ, He D, Chen Z, Jeppesen E, Lauidsen TL, Søndergaard M, Liu ZW, Wu QL (2017) Warming and nutrient enrichment in combination increase stochasticity and beta diversity of bacterioplankton assemblages across freshwater mesocosms. ISME J 11:613-625 doi: 10.1038/ismej.2016.159

Ren LJ, Song XY, He D, Wang JJ, Tan MT, Xia XM, Li G, Tan YH, Wu QL (2019) Bacterioplankton metacommunity processes across thermal gradients: weaker species sorting but stronger niche segregation in summer than in winter in a subtropical bay. Appl Environ Microbiol 85:e02088-18 doi: 10.1128/AEM.02088-18

Sánchez O, Koblížek M, Gasol JM, Ferrera I (2017) Effects of grazing, phosphorus and light on the growth rates of major bacterioplankton taxa in the coastal NW 
Mediterranean. Environ Microbiol Rep 9:300-309 doi: 10.1111/1758-2229.12535

Schauer M, Kamenik C, Hahn MW (2005) Ecological differentiation within a cosmopolitan group of planktonic freshwater bacteria (SOL cluster, Saprospiraceae, Bacteroidetes). Appl Environ Microbiol 71:5900-5907 doi: 10.1128/AEM.71.10.5900-5907.2005

Shen DD, Jürgens K, Beier S (2018) Experimental insights into the importance of ecologically dissimilar bacteria to community assembly along a salinity gradient. Environ Microbiol 20:1170-1184 doi: 10.1111/1462-2920.14059

Song XY, Huang LM, Zhang JL, Huang XP, Zhang JB, Yin JQ, Tan YH, Liu S (2004) Variation of phytoplankton biomass and primary production in Daya Bay during spring and summer. Mar Pollut Bull 49:1036-1044 doi: 10.1016/j.marpolbul.2004.07.008

Stauffer BA, Sukhatme GS, Caron DA (2020) Physical and biogeochemical factors driving spatially heterogeneous phytoplankton blooms in nearshore waters of Santa Monica Bay, USA. Estuaries Coasts 43:909-926 doi: 10.1007/s12237-020-00704-5

Sun CC, Wang YS, Sun S, Zhang FQ (2006) Analysis dynamics of phytoplankton community characteristics in Daya Bay. Acta Ecol Sin 26:3948-3958 doi: 10.3321/j.issn:1000-0933.2006.12.005

Tang DL, Kester DR, Wang ZD, Lian JS, Kawamura H (2003) AVHRR satellite remote sensing and shipboard measurements of the thermal plume from the Daya Bay, nuclear power station, China. Remote Sens Environ 84:506-515 doi: 10.1016/S0034-4257(02)00149-9

Temmink RJ, Christianen MJ, Fivash GS, Angelini C, Boström C, Didderen K, Engel SM, Esteban N, Gaeckle JL, Gagnon K, Govers LL, Infantes E, van Katwijk MM, Kipson S, Lamers LP, Lengkeek W, Silliman BR, van Tussenbroek BI, Unsworth RK, Yaakub SM, Bouma TJ, van der Heide T (2020) Mimicry of emergent traits amplifies coastal restoration success. Nat. Commun 11:3668 doi: 10.1038/s41467-020-17438-4

Van Der Gucht K, Sabbe K, De Meester L, Vloemans N, Zwart G, Gillis M, Vyverman W (2001) Contrasting bacterioplankton community composition and seasonal dynamics in two neighbouring hypertrophic freshwater lakes. Environ Microbiol 3:680-690 doi: 10.1046/j.1462-2920.2001.00242.x

Wang Q, Garrity GM, Tiedje JM, Cole JR (2007) Naive Bayesian classifier for rapid assignment of rRNA sequences into the new bacterial taxonomy. Appl Environ Microbiol 73:5261-5267 doi: 10.1128/AEM.00062-07

Wang YS, Lou ZP, Sun CC, Sun S (2008) Ecological environment changes in Daya Bay, China, from 1982 to 2004. Mar Pollut Bull 56:1871-1879 doi: 10.1016/j.marpolbul.2008.07.017

Wang YM, Pan J, Yang J, Zhou ZC, Pan YP, Li M (2020) Patterns and processes of free-living and particle-associated bacterioplankton and archaeaplankton communities in a subtropical river-bay system in South China. Limnol Oceanogr 65:S161-S179 doi: 10.1002/lno.11314

Wang ZH, Mu DH, Li YF, Cao Y, Zhang YJ (2011) Recent eutrophication and human disturbance in Daya Bay, the South China Sea: dinoflagellate cyst and geochemical evidence. Estuar Coast Shelf Sci 92:403-414 doi: 10.1016/j.ecss.2011.01.015

Webb CO (2000) Exploring the phylogenetic structure of ecological communities: an example for rain forest trees. Am Nat 156:145-155 doi: 10.1086/303378 
Webb CO, Ackerly DD, McPeek MA, Donoghue MJ (2002) Phylogenies and community ecology. Annu Rev Ecol Syst 33:475-505 doi: 10.1146/annurev.ecolsys.33.010802.150448

Wei X, Ni PT, Zhan HG (2013) Monitoring cooling water discharge using Lagrangian coherent structures: A case study in Daya Bay, China. Mar Pollut Bull 75:105113 doi: 10.1016/j.marpolbul.2013.07.056

Whitney F, Crawford W, Harrison P (2005) Physical processes that enhance nutrient transport and primary productivity in the coastal and open ocean of the subarctic NE Pacific. Deep Sea Res Part II Top Stud Oceanogr 52:681-706 doi: 10.1016/j.dsr2.2004.12.023

Wiens JJ, Ackerly DD, Allen AP, Anacker BL, Buckley LB, Cornell HV, Damschen EI, Jonathan Davies T, Grytnes JA, Harrison SP, Hawkins BA, Holt RD, McCain CM, Stephens PR (2010) Niche conservatism as an emerging principle in ecology and conservation biology. Ecol Lett 13:1310-1324 doi: 10.1111/j.1461-0248.2010.01515.x

Wisnoski NI, Lennon JT (2021) Microbial community assembly in a multi-layer dendritic metacommunity. Oecologia 195:13-24 doi: 10.1007/s00442-020-04767-w

Wu H, Peng RH, Yang Y, He L, Wang WQ, Zheng TL, Lin GH (2014) Mariculture pond influence on mangrove areas in south China: Significantly larger nitrogen and phosphorus loadings from sediment wash-out than from tidal water exchange. Aquaculture 426:204-212 doi: 10.1016/j.aquaculture.2014.02.009

Wu ML, Wang YS, Wang YT, Yin JP, Dong JD, Jiang ZY, Sun FL (2017) Scenarios of nutrient alterations and responses of phytoplankton in a changing Daya Bay, South China Sea. J Mar Syst 165:1-12 doi: 10.1016/j.jmarsys.2016.09.004

Xiong JB, Chen HP, Hu CJ, Ye XS, Kong DJ, Zhang DM (2015) Evidence of bacterioplankton community adaptation in response to long-term mariculture disturbance. Sci Rep 5:15274 doi: 10.1038/srep15274

Yuan XC, He L, Yin KD, Pan G, Harrison PJ (2011) Bacterial distribution and nutrient limitation in relation to different water masses in the coastal and northwestern South China Sea in late summer. Cont Shelf Res 31:1214-1223 doi: 10.1016/j.csr.2011.04.012

Zhang QF, Tang FY, Zhou YJ, Xu JR, Chen HP, Wang MK, Laanbroek HJ (2015) Shifts in the pelagic ammonia-oxidizing microbial communities along the eutrophic estuary of Yong River in Ningbo City, China. Front Microbiol 6:1180 doi:10.3389/fmicb.2015.01180

Zhang X, Zhang JP, Shen Y, Zhou CH, Huang XP (2018) Dynamics of alkaline phosphatase activity in relation to phytoplankton and bacteria in a coastal embayment Daya Bay, South China. Mar Pollut Bull 131:736-744 doi: 10.1016/j.marpolbul.2018.05.008

Zhang Y, Li HL, Guo HM, Zheng CM, Wang XJ, Zhang M, Xiao K (2020) Improvement of evaluation of water age and submarine groundwater discharge: A case study in Daya Bay, China. J Hydrol 586:124775 doi: 10.1016/j.jhydrol.2020.124775

Zhou JZ, Ning DL (2017) Stochastic community assembly: does it matter in microbial ecology? Microbiol Mol Biol Rev 81:e00002-17 doi: 10.1128/MMBR.00002-17

Zweifel UL, Norrman B, Hagstrom A (1993) Consumption of dissolved organic carbon by marine bacteria and demand for inorganic nutrients. Mar Ecol-Prog Ser 101:23-23 doi: 10.3354/meps101023 


\section{Figure legends}

Figure 1 Map of sampling locations in the 12 different habitats in the subtropical Daya Bay, Guangdong, China.

Figure 2 The distribution of dominant bacterial taxa in Daya Bay, Actinobacteria (a), Bacteroidetes (b), Cyanobacteria (c), Planctomycetes (d), Alphaproteobacteria (e), and Gammaproteobacteria (f).

Figure 3 The relationships between environmental factors and their correlations with the community structure of the dominant bacterioplankton (sub)phyla. Edge width means the R values of the Mantel's statistic, and edge color represents the statistical significance based on 9,999 permutations (a). The relative abundances of Actinobacteria (b), Bacteroidetes (c), Cyanobacteria (d), Planctomycetes $(\mathbf{e})$ Alphaproteobacteria (f), and Gammaproteobacteria (g) across the phosphate concentration gradient.

Figure 4 The distributions of the top 30 OTUs across the phosphate concentration gradient in Daya Bay.

Figure 5 Non-metric multidimensional scaling (NMDS) ordinations showing the distributions of bacterioplankton community compositions (BCCs) in the Daya Bay according to the geographical locations (a and $\mathbf{b}$ ) or the phosphate concentration gradient (c and d) both based on BCC Bray-Curtis dissimilarity (a and $\mathbf{c}$ ) and weighted UniFrac dissimilarity (b and d). Relating BCC Bray-Curtis (e) and weighted UniFrac (f) dissimilarities with the differences of phosphate concentrations. The 
726 formulas, $\mathrm{R}^{2}$ values, and significances are given in each panel.

727

728 Figure 6 The distributions of the mean nearest taxon distance (MNTD, a) and the

729 standardized effect size of the MNTD (SES.MNTD, b) of bacterioplankton

730 communities according to the three phosphate categories in the Daya Bay. LPC: low

731 phosphate concentration, MPC: medium phosphate concentration, and HPC: high

732 phosphate concentration. 
Figure 1

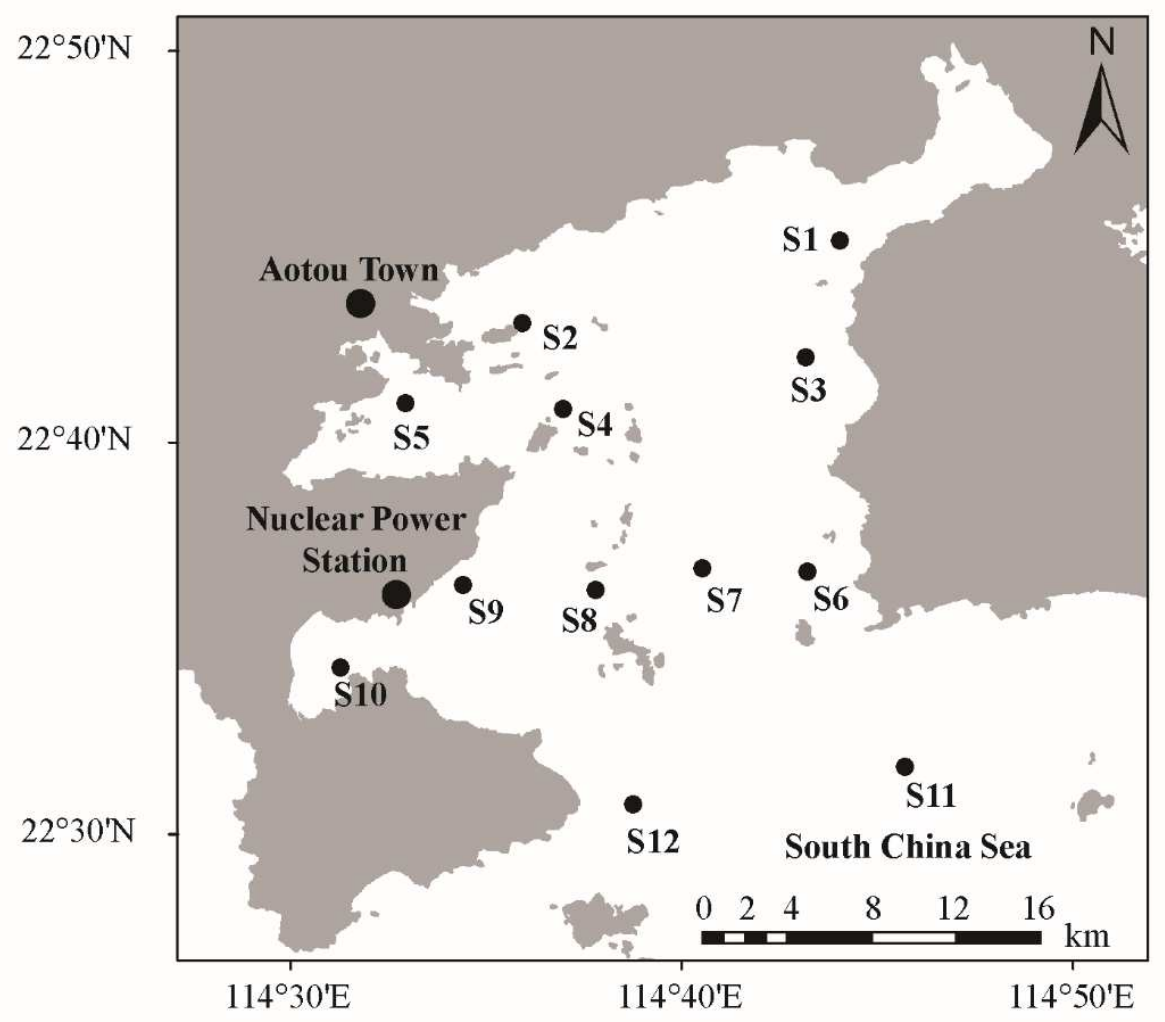

734 
Figure 2

a

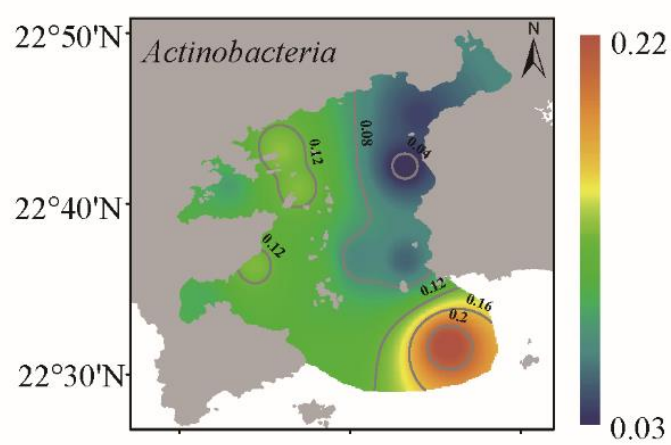

c

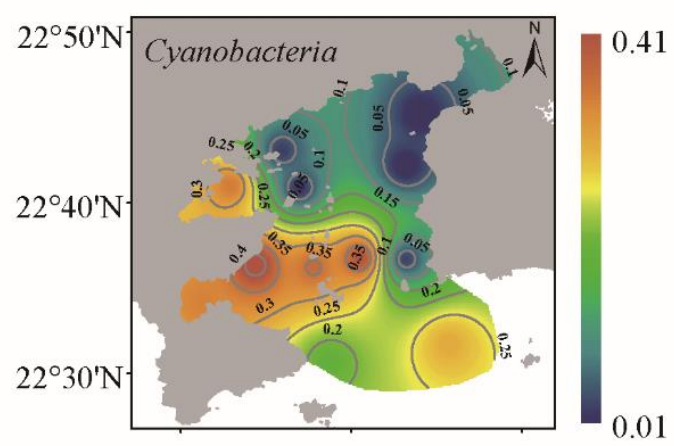

e

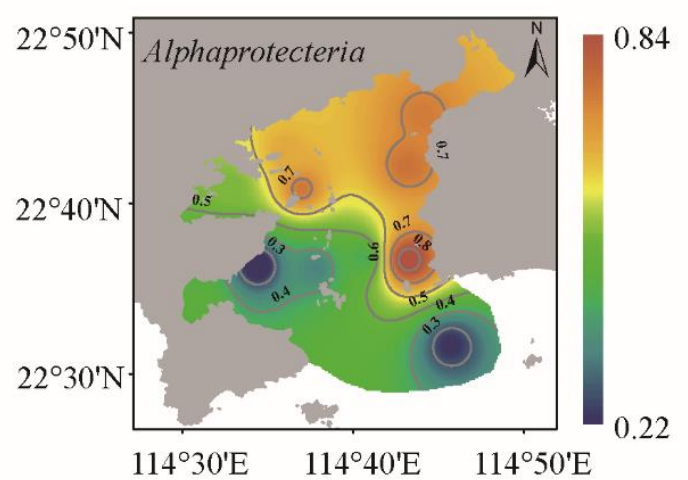

b

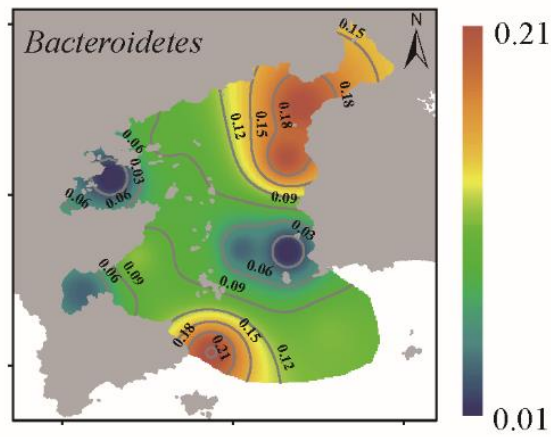

d

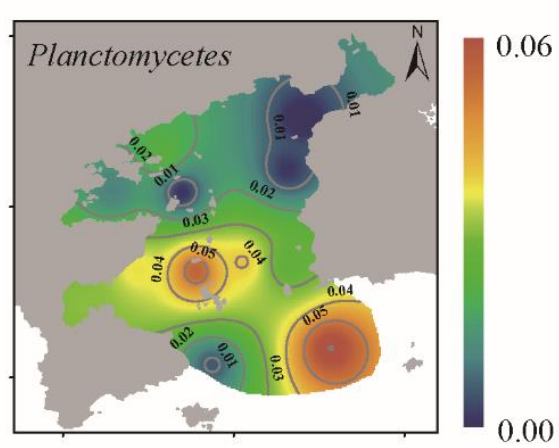

f

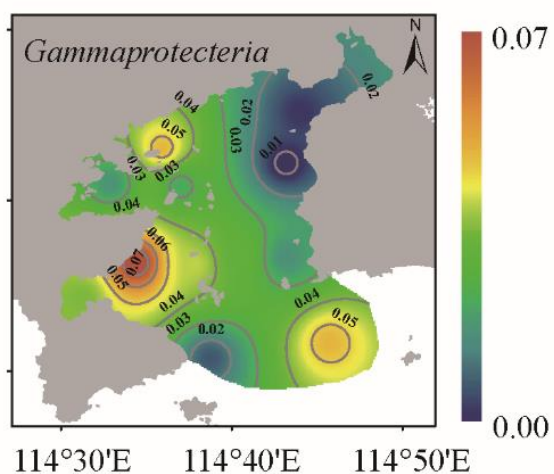


Figure 3

a

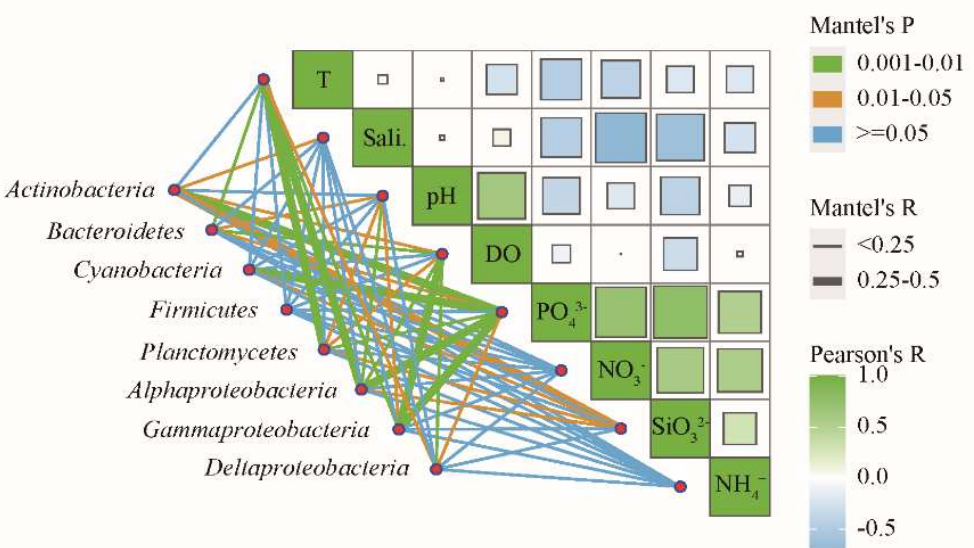

b
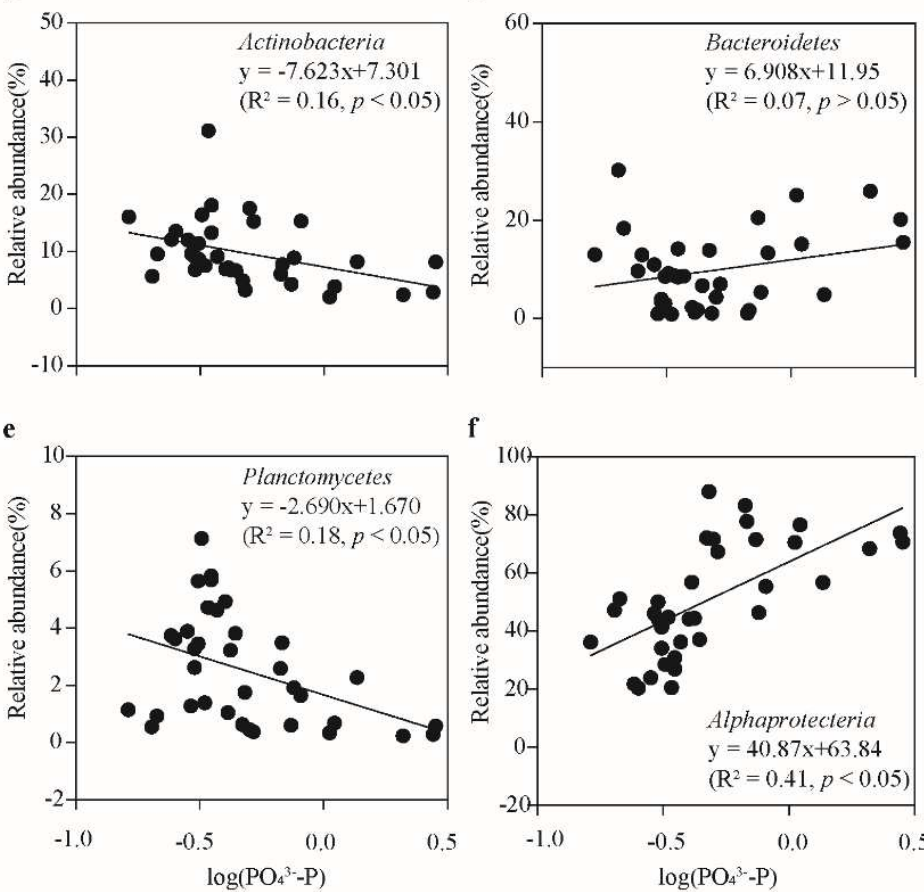

d

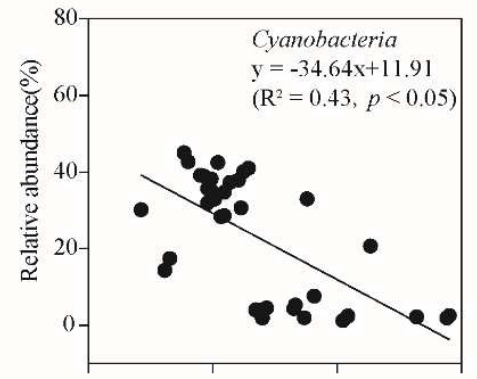

g

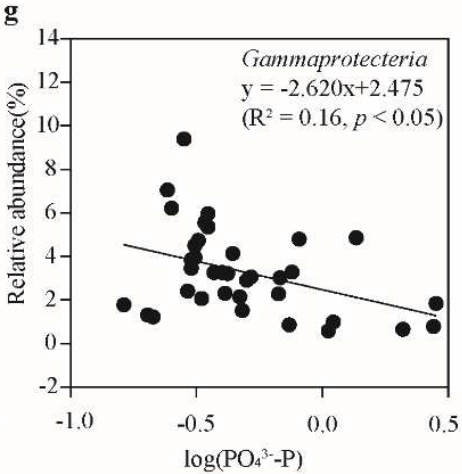


Figure 4

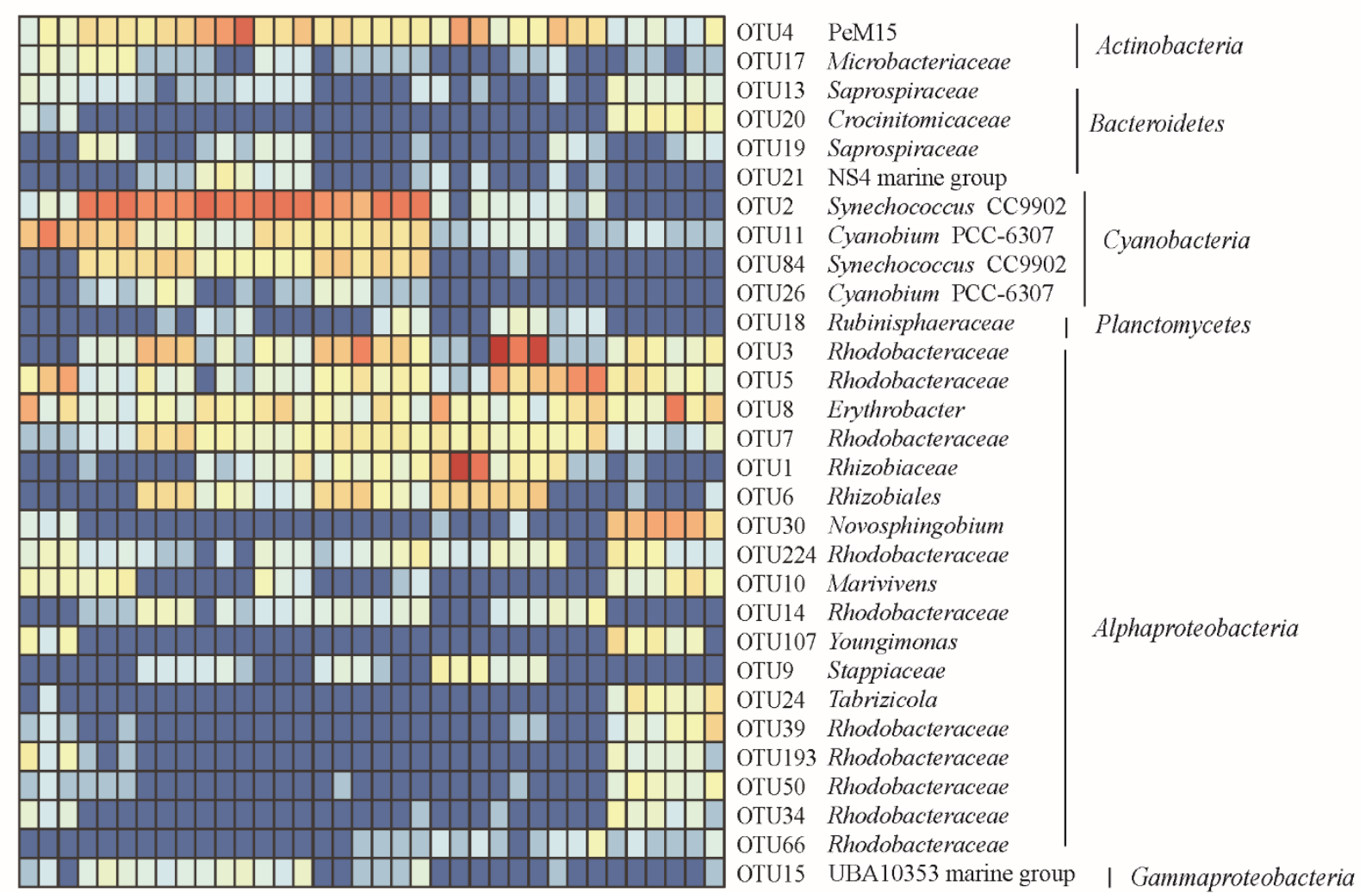

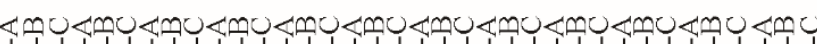

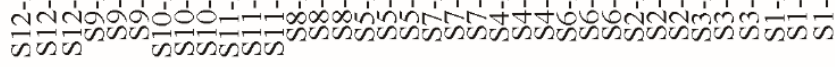

Phosphate concentration Relative abundance $(\%)$ $\begin{array}{llll}\text { I } & 10 & 20 & 30\end{array}$ 
a

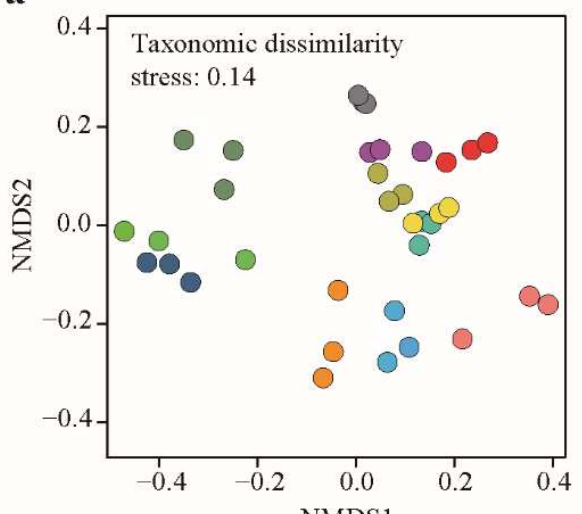

c

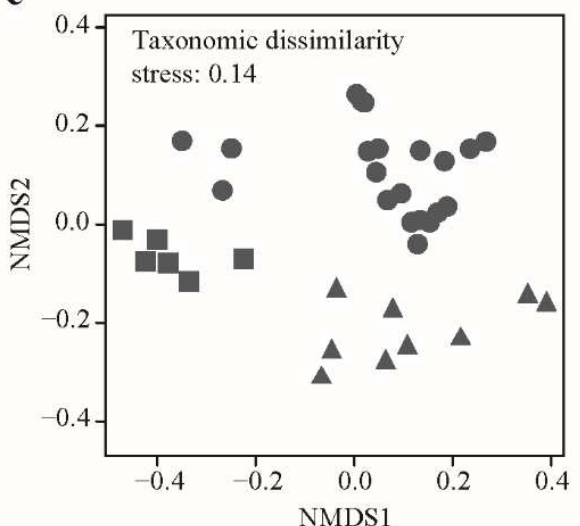

e

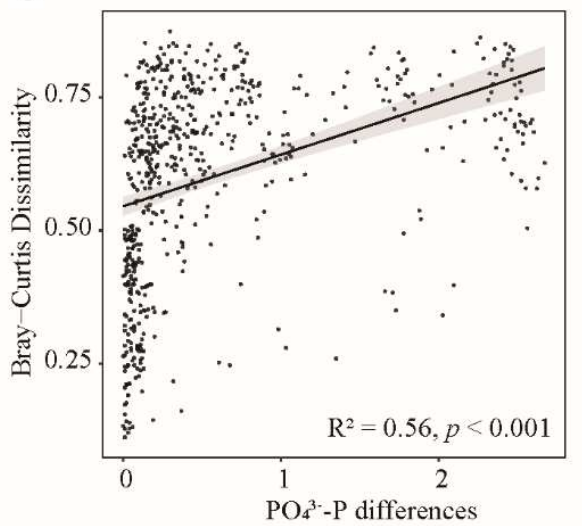

b

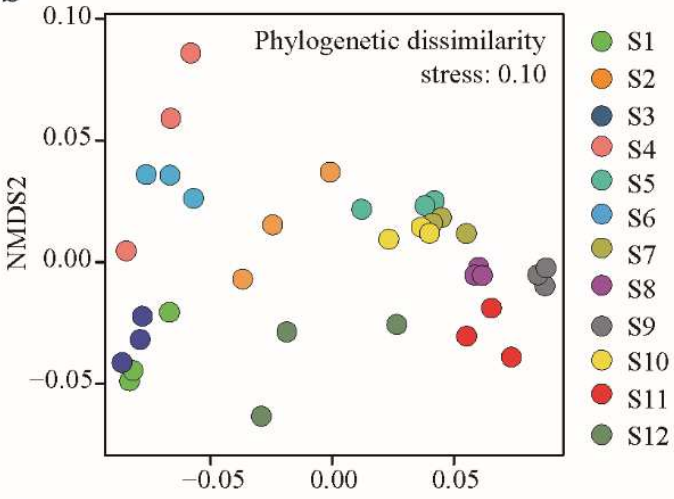

d
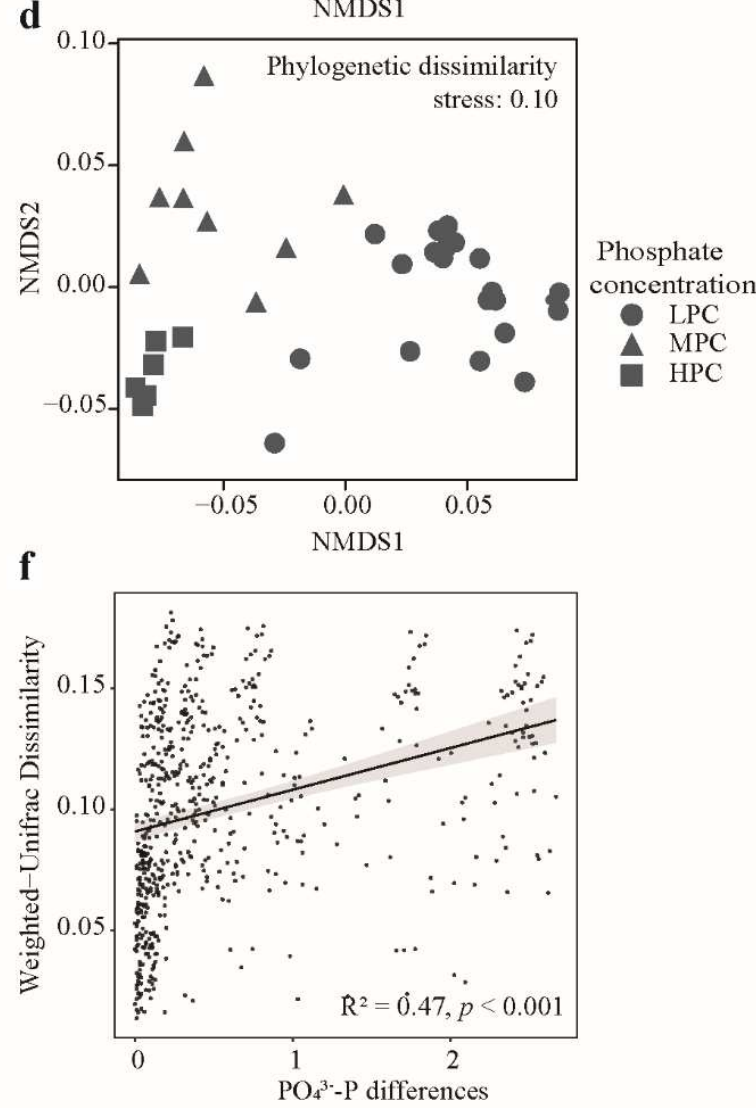
Figure 6
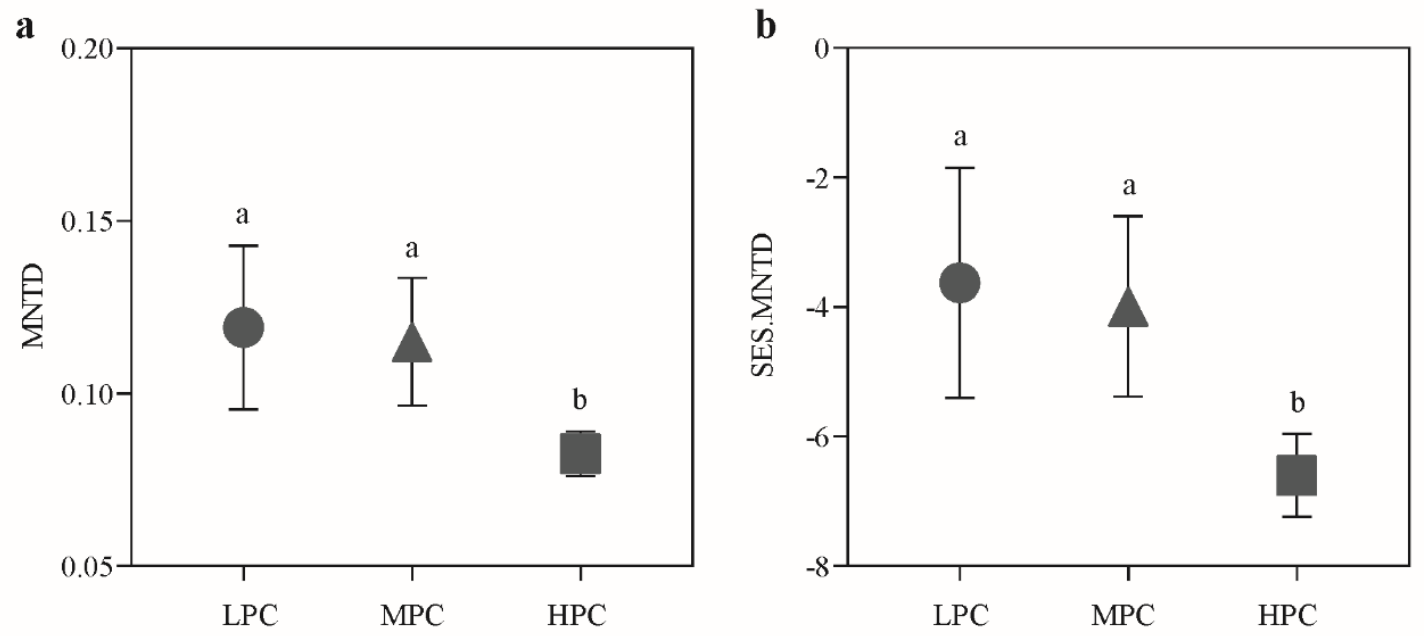


\section{Supplementary Files}

This is a list of supplementary files associated with this preprint. Click to download.

- Supplementalmaterials13.pdf 